\title{
Noscapine inhibits human hepatocellular carcinoma growth through inducing apoptosis in vitro and in vivo
}

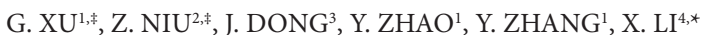

${ }^{1}$ Zhengzhou People's Hospital, Zhengzhou 450003, Henan Province, P.R. China; ${ }^{2}$ Anyang Tumor Hospital, Anyang 455000, Henan Province, P.R. China; ${ }^{3}$ Zhengzhou First People's Hospital, Zhengzhou 450000, Henan Province, P.R. China; ${ }^{4}$ Henan Provincial People's Hospital, Zhengzhou 450000, Henan Province, P.R. China

*Correspondence: xiaosu863@163.com

${ }^{*}$ Contributed equally to this work.

Received January 22, 2016 / Accepted May 31, 2016

\begin{abstract}
Noscapine, a phthalideisoquinoline alkaloid derived from opium, has been demonstrated as a promising anti-tumor compound against various cancers. However, the anti-cancer activity of noscapine in hepatocellular carcinoma has not been defined. In this study, we investigate the inhibitive effects of noscapine on human hepatocellular carcinoma (HCC) using both in vitro and in vivo models. In vitro proliferation assay showed that noscapine suppressed HepG2 and Huh7 cells in dose- and time-dependent manners. With a mouse xenograft model, noscapine showed notable inhibition on HCC tumor growth in vivo without suppression of body weight. Moreover, apoptotic induction and regulation of related signalings by noscapine were examined by nuclear DNA staining, TUNEL, and western blotting assays. Results showed that noscapine induced apoptosis in HCC cells both in vitro and in vivo. Further studies indicated that noscapine induced antive-capsase-3, cleavage PARP, and decreased the ratio of Bcl-2/Bax. Hence, these data indicates that noscapine selectively suppresses HCC cell growth through apoptosis induction, providing evidence for application of noscapine as a novel agent against human hepatocellular carcinoma.
\end{abstract}

Key words: noscapine, hepatocellular carcinoma, apoptosis, toxicity

Hepatocellular carcinoma (HCC) is an aggressive malignant tumor with high prevalence. A recent survey on cancer showed that HCC is one of the most lethal cancers with less than $15 \%$ survival within five years [1]. Currently, although many chemotherapy drugs are employed in clinical, the overall outcome is still unsatisfactory [2]. Selectivity and toxicity of the chemotherapeutic drugs is still the biggest obstacle for liver cancer patients. Therefore, discovering and studying novel compound with high activity in HCC cells and low toxicity in normal cells are required urgently.

Noscapine (Figure 1) is a phthalideisoquinoline alkaloid extracted from the latex of papaver somniferum, the opium poppy. Its IUPAC name is (3S)-6,7-dimethoxy-3-[(5R)-4methoxy-6-methyl-7,8-dihydro-5H-[1,3]dioxolo[4,5-g] isoquinolin-5-yl]-3H-2-benzofuran-1-one. Previously, noscapine is used for treating cough due to its antitussive activity through reducing the histamine-induced contractility of human umbilical cord artery [3]. Later, noscapine is employed for treating stroke due to its property as a noncompetitive antagonist of bradykinin receptors as well as its activity protecting organs against ischemia-reperfusion injury [4]. Recently, accumulating evidence demonstrates that noscapine is a novel anti-cancer agent due to its apoptosis-inducing and metaphase arresting activities. The most important property of noscapine to be an antineoplastic remedy is that noscapine has negligible toxicity and does not suppress humoral or cellmediated immunity [5]. Many studies have been conducted stressing its activity as an anti-tumor agent against a wide range of cancers, such as ovarian cancer [6], glioblastoma [7], non-small Cell Lung Cancer [8], colon cancer [9], and breast cancer [10]. However, effect to noscapine on HCC has not been well defined.

In this study, we focus on the anti-tumor activity of noscapine in hepatocellular carcinoma. Data indicates that noscapine suppresses proliferation of HepG2 and Huh7 cells, as well as inhibits HepG2 tumor growth in a xenograft tumor model. 
Further studies indicate that noscapine exerts its anti-HCC activity through its apoptosis-inducing effect. Collectively, these data show evidence that noscapine selectively inhibits HCC cell growth, providing new mechanism for the application of noscapine serving as a therapeutic candidate for hepatocellular carcinoma treatment.

\section{Materials and methods}

Compound and reagent. Noscapine was freshly prepared in dimethyl sulfoxide (DMSO) to a concentration of 100 $\mathrm{mM}$ as stock solution. This stock solution was then diluted with cell culture medium to the final concentrations needed before each experiment. The 3-(4,5-Dimethylthiazol-2-yl)2,5-Diphenyltetrazolium Bromide (MTT) was from Roche. Antibody against $\beta$-actin, $\mathrm{Bcl}-2$, and Bax were purchased from Santa Cruz Biotechnology (Santa Cruz, CA). Anti-active caspase -3 , active caspase- 9 , cleavage PARP and survivin were from Cell signaling (Beverly, MA). Immobilon Western Chemiluminescent HRP Substrate was from Thermo Scientific. Ln. All chemicals and reagents not included above were purchased from Sigma-Aldrich (St. Louis, MO).

Cell lines and mice. Human hepatocellular carcinoma HepG2 and Huh7 cells were cultured in DMEM medium. Human normal hepatic cell line L02 was cultured in RPMI1640 medium. The culture medium was supplemented with $10 \%$ FBS and $1 \times$ pen/strep/glutamine. The culture medium was supplemented with $10 \% \mathrm{FBS}$ and $1 \times$ pen/strep/glutamine. Cells were maintained at $37^{\circ} \mathrm{C}$ with $5 \% \mathrm{CO}_{2}$ atmosphere in a humidified incubator. Female athymic BALB/c nude mice (35-40 days old) with body weight ranging from 18 to $22 \mathrm{~g}$ were maintained at $22 \pm 2{ }^{\circ} \mathrm{C}$ and $55-65 \%$ humidity in stainless steel cages under controlled lights ( 12 hours light/day). The animal care and experiments with animals were carried out according to the recommendations of the Guide for the Care and Use of Laboratory Animals published by the National Institute of Health, USA.

Cell proliferation assay. Cells were seeded in 96-well plates ( 35000 cells/ well) for noscapine treatment. The next day, the medium was replaced with fresh medium containing different concentrations of the noscapine or vehicle controls. Triplicate experiments were performed in a parallel manner for each concentration point. After 24, 48, and 72 hours of incubation, the culture medium was removed and the cells washed twice with PBS. MTT assay was carried out as described with little modification [11]. Then $0.5 \mathrm{mg} / \mathrm{ml}$ MTT solution was added to each well. The cells were further incubated at $37^{\circ} \mathrm{C}$ for 4 hours. The supernatant was discarded and $100 \mu \mathrm{l}$ of dimethyl sulfoxide (DMSO) was added to each well. The mixture was shaken on a micro-vibrator for $5 \mathrm{~min}$ and the absorbance was measured at $570 \mathrm{~nm}$.

Flow cytometric analysis. Following treatment of noscapine or vehicle control for 24 hours, cells were collected and treated with washed twice with ice-cold PBS, and fixed in $70 \%$ ethanol. Then the cells stored at $-20{ }^{\circ} \mathrm{C}$ for 24 hours.

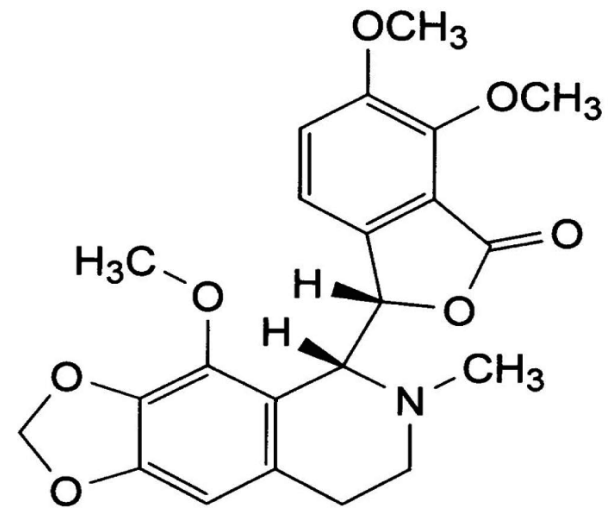

Figure 1. Chemical structure and atom numbering scheme of noscapine $\left(\mathrm{C}_{22} \mathrm{H}_{23} \mathrm{NO}_{7}\right.$; $\left.\mathrm{MW} 412.4\right)$.

Then the cells were centrifuged at $3000 \mathrm{rpm}$ for $10 \mathrm{~min}$ and the supernatant was discarded. Cells were then washed with $5 \mathrm{ml}$ of PBS and incubated with propidium iodide $(20 \mu \mathrm{g} / \mathrm{ml})$ /RNase A $(20 \mu \mathrm{g} / \mathrm{ml})$ in PBS for 45 minutes. After incubation, the samples were analyzed by flow cytometer and analysis FlowJo software.

Tumor xenograft studies. HepG2 cells $\left(4 \times 10^{6}\right)$ in $100 \mu \mathrm{l}$ of serum free DMEM medium were injected subcutaneously into one flank of the nude mice described above. After the xenograft tumor grow to $50 \mathrm{~mm}^{3}$. The mice were randomly divided into three groups ( 7 mice/group) treated orally with vehicle and noscapine $(75,150,300 \mathrm{mg} / \mathrm{kg})$ diluted in acidified deionised water ( $\mathrm{pH} 4.0$ ). The dosages were determined based on previous studies $[5,12,13]$. Treatments were continued for 40 days. Body weight was determined at the end of experiment and tumors were measured every three days after the initiation of treatment. Tumor volumes were determined by measuring two perpendicular diameters using callipers; the volume was then determined using the formula (length $x$ width $^{2}$ ) / 2, where length was the longest axis and width being the measurement at right angles to the length [11].

TUNEL and immunochemistry staining. Apoptosis in tumor tissues was detected using an in situ cell death detection kit (Roche Diagnostics, USA) [14]. Specifically, tumors were fixed in $4 \%$ paraformaldehyde for overnight followed by paraffin embedding. Sections $(8 \mu \mathrm{m})$ were deparaffinized in xylene and rehydrated in graded alcohols. The slide were then covered by proteinase $\mathrm{K}(10 \mu \mathrm{g} / \mathrm{ml})$ and incubated for 15 minutes at room temperature. Following $0.1 \%$ TritonX-100 treatment, tumor tissue apoptosis was detected using an in situ cell death detection kit (Roche Diagnostics, USA). For immunochemistry staining, endogenous peroxidase activity in the section slides was blocked by $3 \%$ hydrogen peroxide for 5 minutes and slides were boiled in $10 \mathrm{mM}$ citrate buffer $(\mathrm{pH}$ 6.0) for 10 minutes. Protein expressions/nucleus were detected using specific antibodies and Zymed Histo-SP AEC kit according to the instruction provided by the manufacture. 

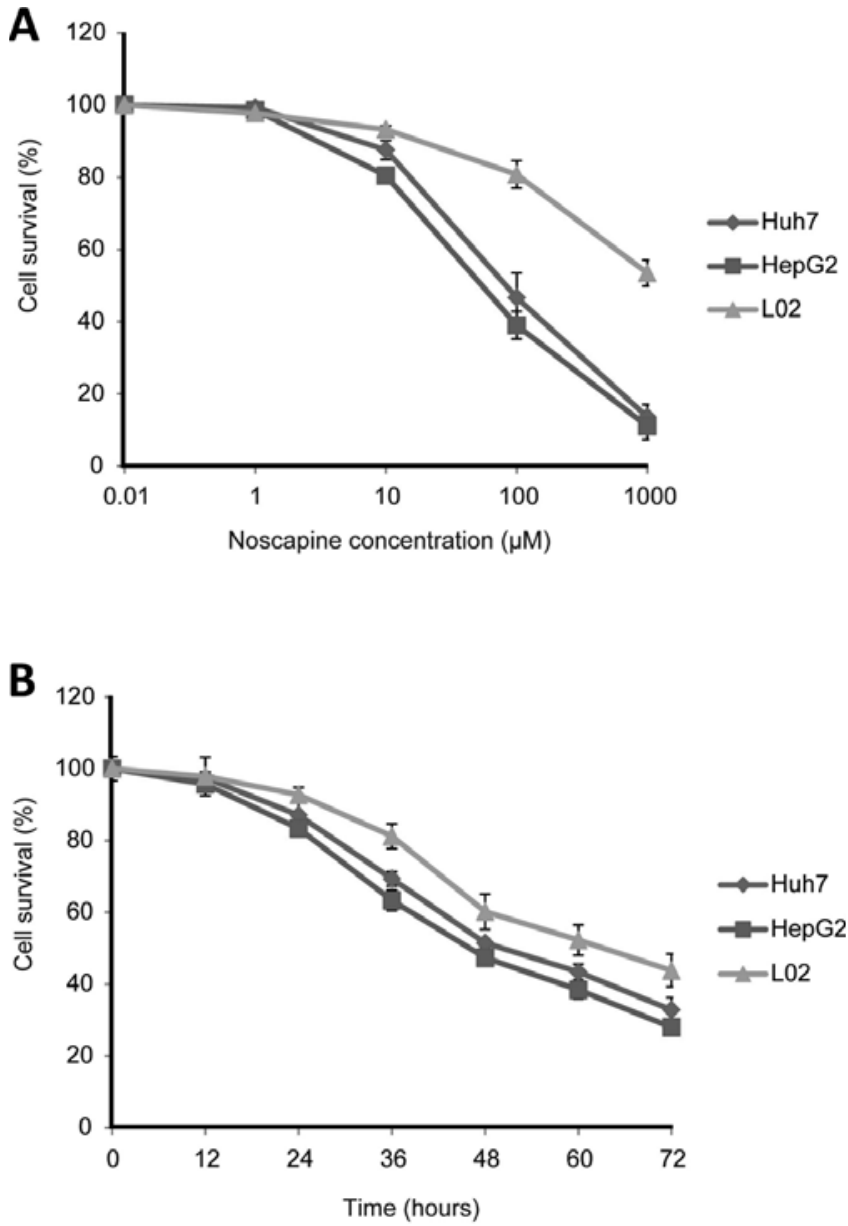

Figure 2. Noscapine suppresses HepG2 and Huh7 cells in dose- and time-dependent manners. A. Cells were treated with indicated concentrations of noscapine followed by MTT assay analysis. Noscapine dosedependently inhibited proliferation of the HCC cells. B. HepG2 and Huh7 cells treated with noscapine at the concentration of IC50 followed by MTT assay. Within 72 hours, noscapine time-dependently suppress HCC cell proliferation.

Western blot analysis. Western blotting assay was carried out as described with little modification [15]. Cells were lysed in RIPA buffer and centrifuged for 15 minutes at $4{ }^{\circ} \mathrm{C}$. Total protein was quantified using the Bradford reagent, and equal amounts of total protein were mixed with $4 \times$ SDS sample buffer, incubated at $95{ }^{\circ} \mathrm{C}$ for 5 minutes, and separated by SDS-PAGE. After electrophoresis, proteins were transferred to a nitrocellulose filter membrane (Bio-Rad, MA, USA) and blocked for 1 hours at room temperature. Each membrane was incubated with the appropriate primary antibody at $4{ }^{\circ} \mathrm{C}$ for overnight. The blots were then incubated with HRPconjugated secondary antibodies for 1 hour, washed three times with PBST, and visualized using the Immobilon Western Chemiluminescent HRP Substrate.

Statistical analysis. Data are presented as the mean \pm SD of two or three independent experiments. Statistical evalu-
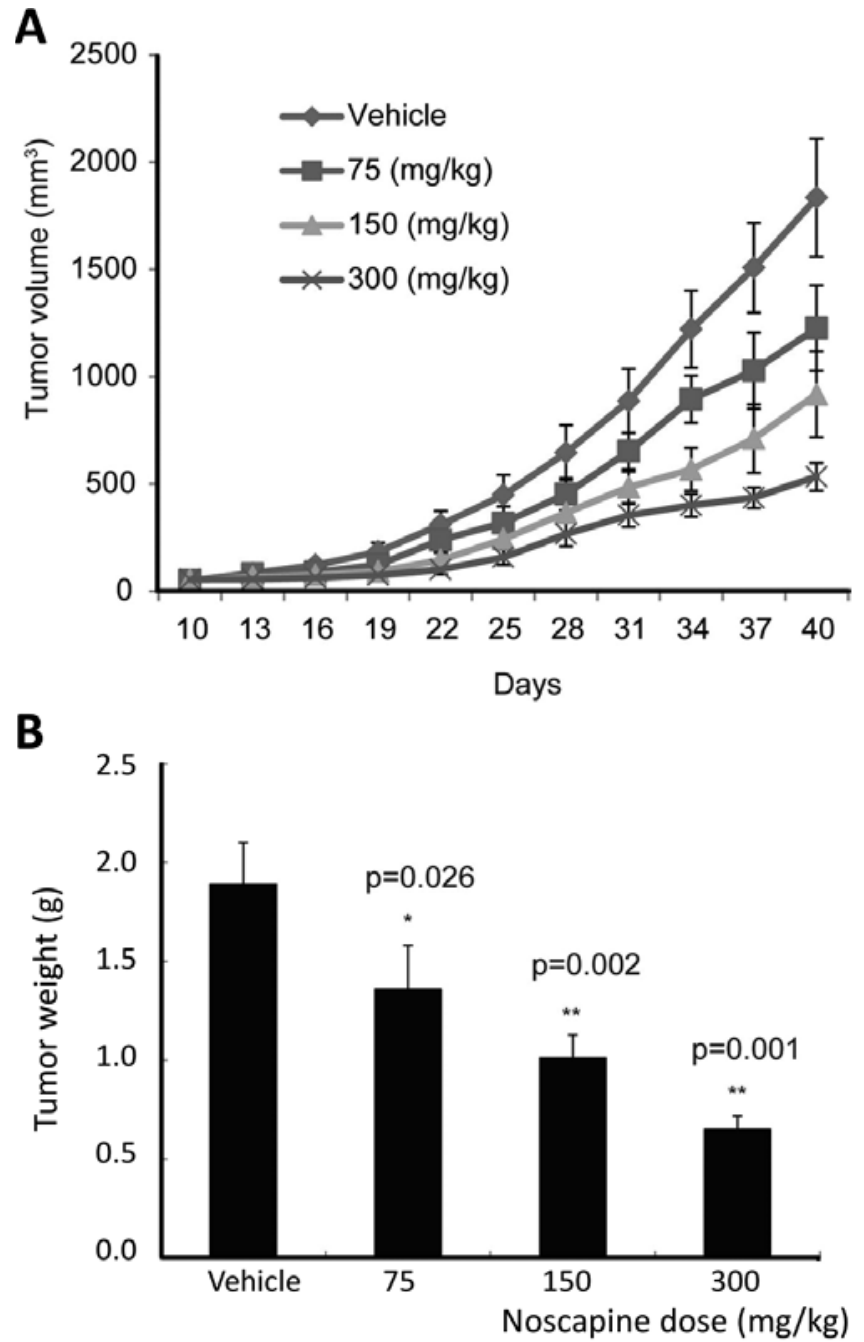

C

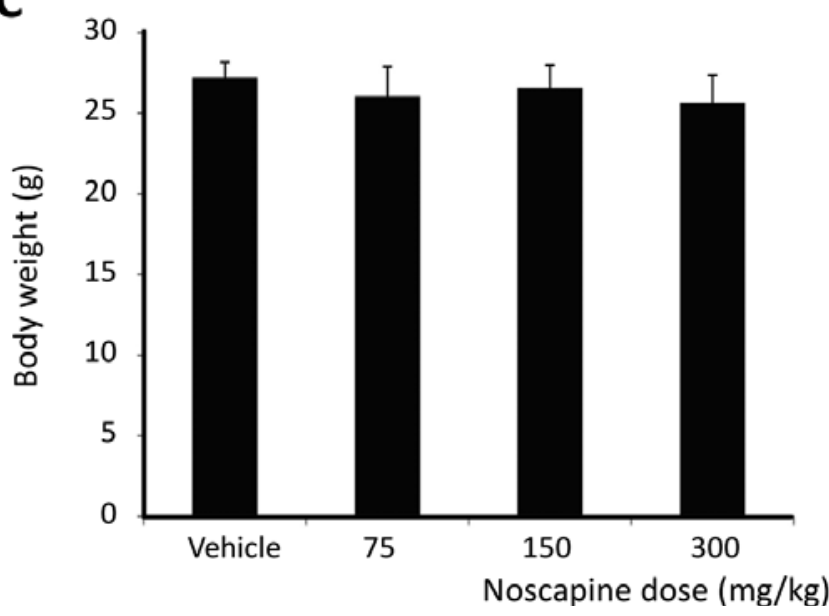

Figure 3. Noscapine suppresses HepG2 xenograft tumor growth in vivo. HepG2 cells were inoculated subcutaneously in nude mice, tumors were allowed to form, and then mice were treated with drugs, as described in Materials and Methods. Tumor volumes (A), tumor weight (B), and body weight $(C)$ were examined throughout the experiment. Data represent the mean \pm SD $\left({ }^{\star} \mathrm{P}<0.05,{ }^{\star *} \mathrm{P}<0.01, \mathrm{n}=7\right.$ /group $)$. 
A

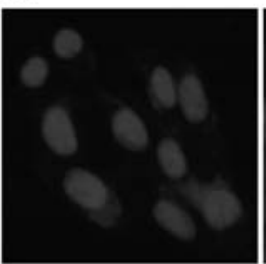

Vehicle

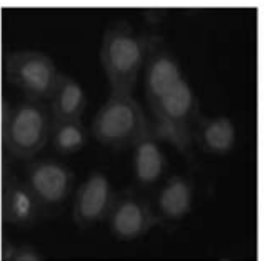

25

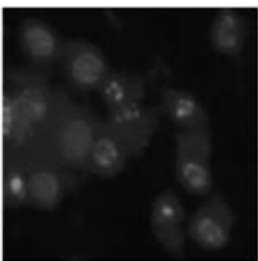

50

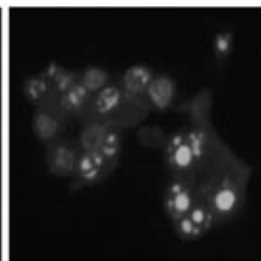

100

Noscapine $(\mu \mathrm{M})$

B

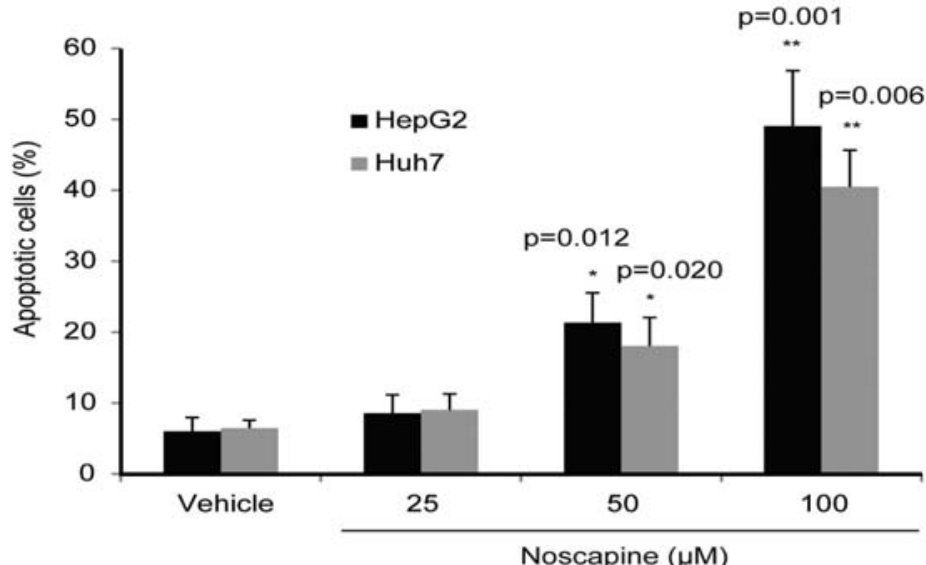

C

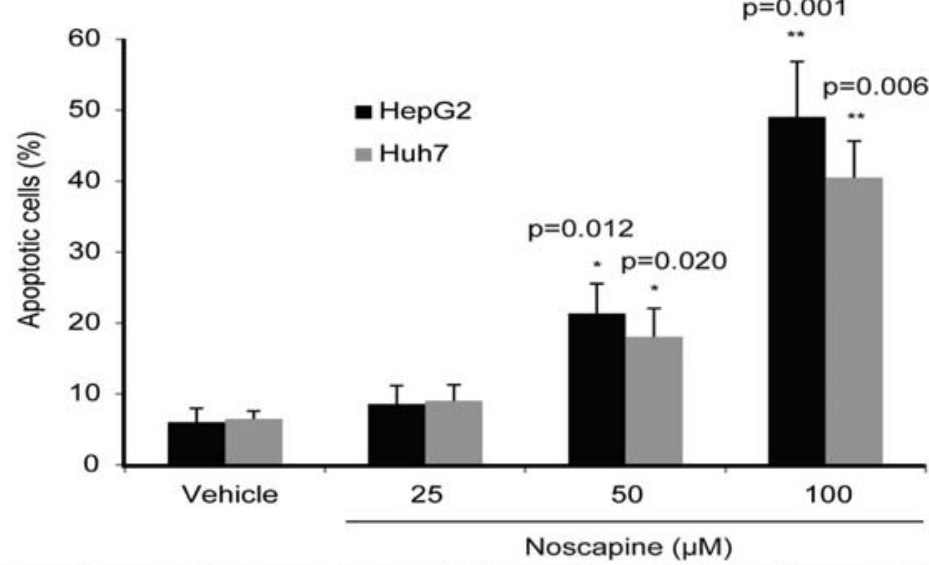

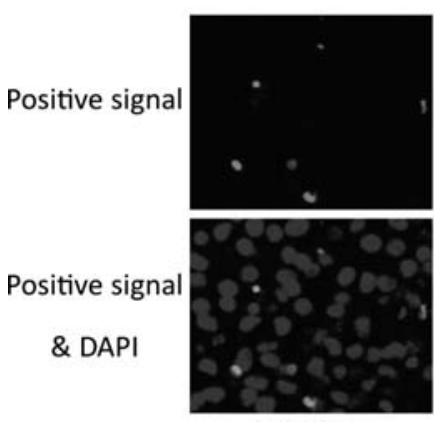

Vehicle
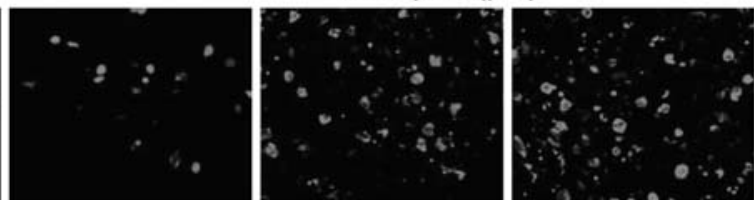

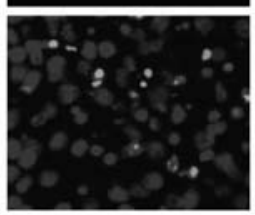

75 (mg/kg)

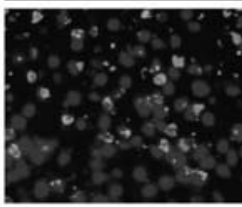

150 (mg/kg)

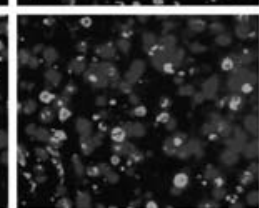

300 (mg/kg)

Figure 4. Noscapine induces apoptosis in HepG2 cells in vitro and in vivo. A. Fluorescent staining of nuclei by DAPI in noscapine or vehicle treated cells followed by observation using fluorescence microscope. B. Quantification of apoptotic cells in groups treated with or without noscapine using flow cytometry. Data are present as mean $\pm \mathrm{SD}{ }^{\star} \mathrm{P}<0.05,{ }^{*} \mathrm{P}<0.01$ vs. control group. C. With tumor tissue sections, TUNEL staining analysis indicated that noscapine induced apoptosis in vivo. 
ation was performed using the Student's t-test or one-way ANOVA. Differences were considered to be statistically significant when $\mathrm{P}<0.05$. All statistical analyses were performed using Prism software (Graph Pad Software, La Jolla, CA, USA)

\section{Results}

Effect of noscapine on cell proliferation of hepatocellular carcinoma (HCC) cells in vitro. It has been reported that noscapine suppresses cancers derived from various organs. However, the effect of noscapine on HCC cells has not been defined. To address this question, two HCC cell lines, HepG2 and Huh7 were employed. First, we treated the two cell lines with different concentrations $(0,1,10,100,1000 \mu \mathrm{M})$ of noscapine for 48 hours, then MTT assay was employed for assessing the inhibition of cell proliferation by noscapine. As shown in Figure 2A, noscapine dose-dependently inhibited cell proliferation with the IC50 values of 50.53 and $74.14 \mu \mathrm{M}$ in HepG2 and Huh7 cells, respectively, whereas exerted neglect effect on human normal hepatic L02 cells, demonstrating the cell specificity of noscapine. Using the IC50 concentrations, time-dependently analysis was carried out to further investigate the inhibitory activity of noscapine in the HCC cells. Data showed that noscapine suppressed cell proliferation also in a time-dependent manner within 72 hours (Figure 2B), while the vehicle treatment did not affect the proliferation of cells (Supplemental figure 1). Collectively, these data suggest that noscapine suppresses HCC cells in both dose- and timedependent manner.

Effect of noscapine on HCC growth in vivo. To further confirm the anti-HCC activity in vitro, xenograft tumor model was established through inoculating HepG2 cells subcutaneously. Mice with implanted tumors were then treated with control, 75,150 , and $300 \mathrm{mg} / \mathrm{kg}$ for 40 days and data of tumor volumes and tumor weights at the end of the experiment were collected. The tumor volume in noscapine treated mice was less than that in control mice at the same measurement day and $300 \mathrm{mg} / \mathrm{kg}$ noscapine treated mice showed the strongest inhibitive effect on tumor growth after 2 weeks treatment (Figure 3A). In addition, following the treatment, none of the mice in either treatment group died during the course of the experiment. Also, the weight of tumors from the mice treated with noscapine was less than that from the vehicle controls (Figure 3B). Body weights examination showed that no apparent changes in body weight and no significant differences among the control and noscapine treated groups (Figure 3C), suggesting that noscapine had no significant toxicity within the dose of $300 \mathrm{mg} / \mathrm{kg}[16,17]$. Together, these data suggest noscapine selectively suppresses HCC tumor growth in vivo.

Noscapine induces apoptosis of HCC cells in vitro and in vivo. Since apoptosis inducing activity is the most important property of noscapine contributing its anti-cancer ability. We go on checking whether noscapine promotes apoptosis in HCC cells or not. Following treatment with noscapine at different concentrations for 24 hours, DNA staining was employed with DAPI. As shown in Figure $4 \mathrm{~A}$, control cells emitted uniform blue fluorescence, which indicated that chromatins of the vehicle treated cells were equally distributed in the nucleus, whereas the cells treated with noscapine, especially in 50 and $100 \mu \mathrm{M}$ treated groups, displayed congregated chromatins and emitted bright fluorescence as well as nucleolus pyknosi. The fluorescence intensity increased with increasing concentrations of noscapine, which indicated that noscapine induced apoptosis in a dose-dependent manner. To confirm the apoptosis inducing activity of noscapine in HCC cell, HepG2 and Huh7 cells were treated followed PI staining and flow cytometry analysis. Quantification analysis of the apoptosis in vehicle and noscapine treated groups showed that noscapine indeed induced apoptosis in HCC cells (Figure 4B). To further study the apoptotic activity of noscapine in HCC, tumor tissues from the in vivo experiment were fixed and sectioned for TUNEL staining. As shown in Figure 4C, sections from noscapine treated groups showed more TUNEL positive signals, indicating that noscapine induced apoptosis in vivo. Quantification of the positive cells from section of each groups showed that noscapine induced apoptosis in tumor in a dose-dependent manner (Figure 4C).

Effects of noscapine on apoptotic signaling pathway in vitro and in vivo. To further study the mechanism by which noscapine suppresses HCC cell growth in vitro and in vivo, western blotting assay was employed to examine the regulation of apoptotic signaling by noscapine. First, we collected the cell lysates from HepG 2 cells treated with increasing concentrations of noscapine $(25,50$, and $100 \mu \mathrm{M})$ for 24 hours and detected the expression of apoptosis related molecules. Then levels of cleavage caspase- 3 and cleavage PARP were examined with the cell lysates. Results showed that noscapine enhanced the expressions of cleavage caspase-3, -9 and PARP, while decreased survivin in a concentration-dependent manner (Figure 5A and 5B), indicating the apoptosis inducing activity in HCC cells. Immunochemistry staining also showed that noscapine could induce active caspass-3 and cleavage PARP compared to vehicle group (Figure 5C), which were consistent with the results shown in Figure 4. With the lysates from treated cells and tumor tissues from mice treated with different dosage of noscapine, we further detected the expression of $\mathrm{Bcl}-2$ and Bax. As shown in Figure $5 \mathrm{~A}$, noscapine decrease $\mathrm{Bcl}-2$ expression in a dose-dependent manner in vitro, while no significant changed of Bax levels among groups. In vivo, level of Bcl-2 also decreased upon noscapine treatment. However, expression of Bax in the $300 \mathrm{mg} / \mathrm{kg}$ noscapine treated group was upregulated (Figure $5 \mathrm{D}$ and $5 \mathrm{E}$ ). These data suggest that noscapine induces apoptosis in HCC cells apoptosis through down-regulating of the ratio of $\mathrm{Bcl}-2 / \mathrm{Bax}$, promoting cleavages of caspase-3, -9 and PARP. 
A

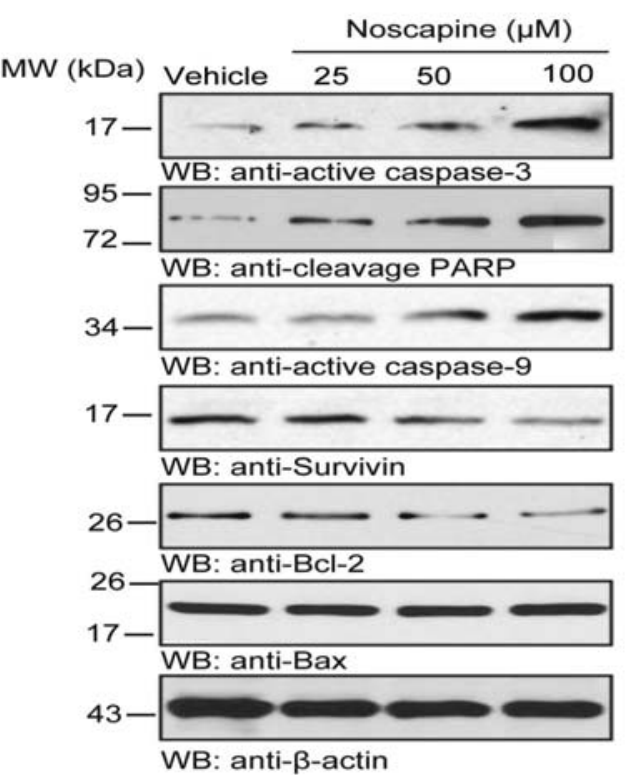

B

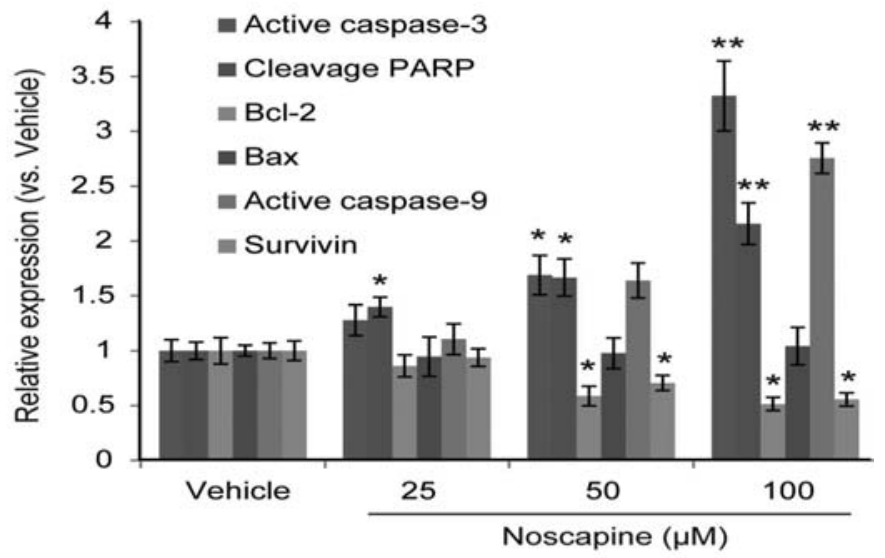

Noscapine $(\mathrm{mg} / \mathrm{kg})$

C

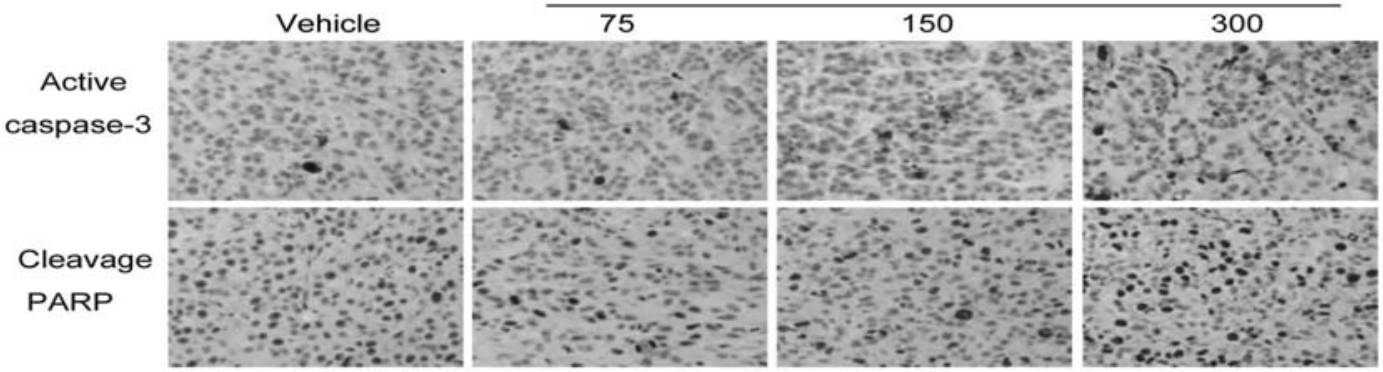

D

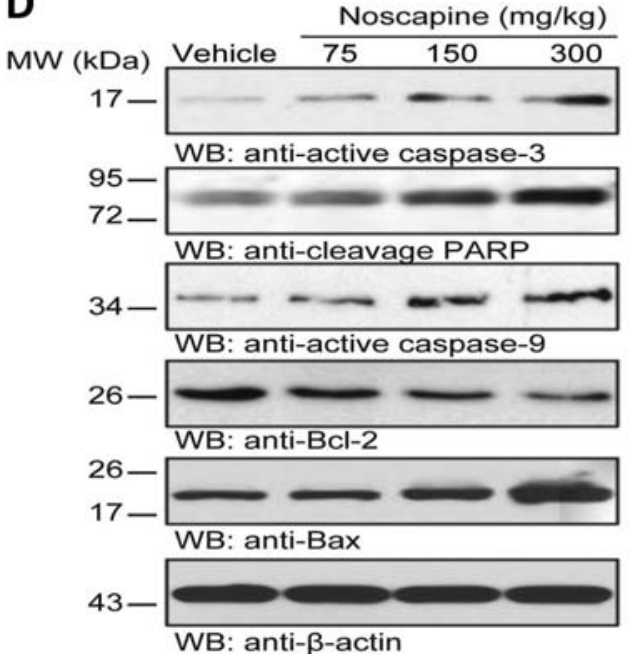

E

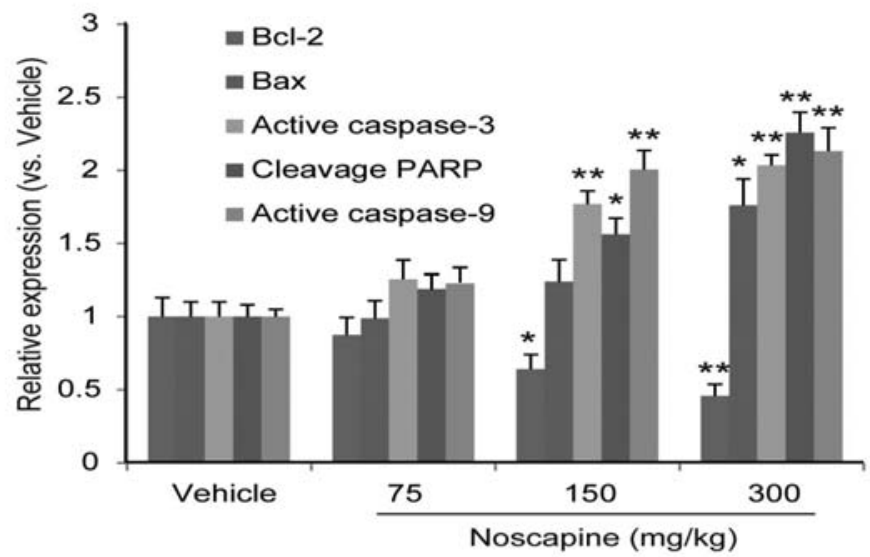

Figure 5. Effect of noscapine on apoptosis related signaling in vitro and in vivo. A. Effect of noscapine on apoptosis related signaling in HepG2 cells treated with different concentrations of noscapine. Treated cells were collected and cell lysates were used for western blotting analysis with indicated antibodies. B. Quantification of the western blotting data of $A$. Data are present as mean $\pm S D{ }^{\star} P<0.05,{ }^{* *} P<0.01$ vs. control group. C. Noscapine enhanced active-caspase-3 expression and cleavage PARP in vivo. Immunohistochemistry staining of active-caspase- 3 and cleavage PARP in tumor sections derived from animals treated with noscapine. Brown represents the positively staining cells. D. Effect of noscapine on apoptosis related signaling in HepG2 transplanted tumors treated with different concentrations of noscapine. Tumor tissues from the groups treated with or without noscapine were collected and cell lysates were used for western blotting analysis with indicated antibodies. E. Quantification of the western blotting data of $D$. Data are present as mean $\pm \mathrm{SD}{ }^{\star} \mathrm{P}<0.05,{ }^{* *} \mathrm{P}<0.01$ vs. control group. 


\section{Discussion}

Liver cancer is the second cause of cancer death after lung cancer and the number of the patient are increasing [18]. Hepatocellular carcinoma (HCC) is most frequent liver cancer. It is among the tumors with the lowest response to current chemotherapy, which is due either to the existence of refractoriness of the initial tumor or to the ability of cancer cells to develop chemo-resistance during treatment [19]. Therefore, new drugs are needed urgently. Noscapine is a safe orally active microtubule agent and exerts in vitro and in vivo antitumor activity against variety of cancers $[6,20]$. It is also demonstrated as an apoptosis inducer functioning in different kinds of tumors [21-24]. Thus, it is expected that noscapine may exert anticancer activity in human HCC.

In this study, we show that noscapine suppresses HCC cell proliferation both in time- and dose-dependent manners (Figure 2). Moreover, it exhibits anti-tumor activity against HCC xenograft without significant weight decrease (Figure 3). These results represents that noscapine exerts a strong antiHCC activity in vivo and might be with low toxicity, suggesting that noscapine should be further explored as a possible therapeutic agent for the treatment of human HCC. Upon previous research, the anti-HCC activity of noscapine may be due to its apoptosis-inducing effect. Then we examine the apoptosis related phenomenon in vitro and in vivo, such as chromatin condensation and chromosomal DNA fragmentation. Our results from DAPI and TUNEL staining demonstrate that noscapine induces HCC cell apoptosis in a dose-dependent manner (Figure 4). The induction of apoptosis through extrinsic or intrinsic death pathways results in the activation of initiator caspases, then active effector caspase, such as caspase-3. PARP is involved in the repair of DNA damage induced by certain anticancer agents and or radiation [12]. It is a known substrate of caspases and its cleavage is also a marker of apoptosis. Our investigation shows that the noscapine can induce caspase- 3 activity and upregulate PARP cleavage both in cells and in tissues, further demonstrating the apoptosisinducing activity of noscapine in HCC.

The anti-apoptotic Bcl-2 protein helps to block apoptosis cascade by preventing the release of mitochondrial apoptogenic factors, presumably via interaction with the mitochondrial porin channel [25]. Bax, proapoptotic protein, is responsible for the release of mitochondrial intermembrane space proteins, such as cytochrome c, Smac/Diablo, EndoG, Omi/HtrA2 and AIF $[11,16]$. The ratio Bax/Bcl-2 have been demonstrated as an indicator of apoptosis and regulation of the ratio is one of the mechanisms involving apoptosis induction $[26,27]$. Accumulating evidence shows that natural compounds induce apoptosis in cancer through changing the ration of Bax/Bcl-2, such as curcumin [28], berberine [29], and so on. Significant decrease of $\mathrm{Bcl}-2$ suggesting that mitochondrial dysfunction is involved in the apoptosis in HCC cells. It is interesting that noscapine had no notable effect on Bax in vitro, while Bax level was increased at highest dosage in vivo (Figure 5). It is possible that long treatment of noscapine regulates the degradation of Bax in the in vivo system [30,31]. This hypothesis will be tested in our future study. Collectively, evidence collected in both in vivo and in vitro systems in the present study demonstrate that the anti-HCC activity of noscapine is due to its potent apoptosis inducing effect. Further study indicated that noscapine induces HCC cell apoptosis through decreasing the ratio of $\mathrm{Bcl}-2 / \mathrm{Bax}$. These data provide more mechanistic insights into noscapine anti-tumor activities and render that noscapine could be served as a potential therapeutic candidate for treatment of human hepatocellular carcinomas.

Supplementary information is available in the online version of the paper.

\section{References}

[1] DE ANGELIS R, SANT M, COLEMAN MP, FRANCISCI S, BAILI $P$ et al. Cancer survival in Europe 1999-2007 by country and age: results of EUROCARE--5-a population-based study. Lancet Oncol 2014; 15: 23-34. http://dx.doi.org/10.1016/ $\underline{\text { S1470-2045(13)70546-1 }}$

[2] NAULT JC Reports from the International Liver Cancer Association (ILCA) congress 2014. J Hepatol 2015; 62: 477-482.

[3] MAHMOUDIAN M, MOJAVERIAN N Efffect of noscapine, the antitussive opioid alkaloid, on bradykinin-induced smooth muscle contraction in the isolated ileum of the guinea-pig. Acta Physiol Hung 2001; 88: 231-237. http:// dx.doi.org/10.1556/APhysiol.88.2001.3-4.5

[4] KHANMORADI M, ALI MARD S, ABOUTALEB N, NOBAKHT M, MAHMOUDIAN The protective activity of noscapine on renal ischemia-reperfusion injury in male Wistar rat. Iran J Basic Sci 2014; 17: 244-249.

[5] KE Y, YE K, GROSSNIKLAUS HE, ARCHER DR, JOSHI HC et al. Noscapine inhibits tumor growth with little toxicity to normal tissues or inhibition of immune responses. Cancer Immunol Immunother 2000; 49: 217-225. http://dx.doi. org/10.1007/s002620000109

[6] ZHOU J, GUPTA K, YAO J, YE K, PANDA D et al. Paclitaxel-resistant human ovarian cancer cells undergo c-Jun $\mathrm{NH} 2$-terminal kinase-mediated apoptosis in response to noscapine. J Biol Chem 2002; 277: 39777-39785. http://dx.doi. org/10.1074/jbc.M203927200

[7] QI Q, LIU X, LI S, JOSHI HC, YE K Synergistic suppression of noscapine and conventional chemotherapeutics on human glioblastoma cell growth. Acta Pharmacol Sin 2013; 34: 930-938. http://dx.doi.org/10.1038/aps.2013.40

[8] CHOUGULE M, PATEL AR, SACHDEVA P, JACKSON T, SINGH M Anticancer activity of Noscapine, an opioid alkaloid in combination with Cisplatin in human non-small cell lung cancer. Lung Cancer 2011; 71: 271-282. http://dx.doi. org/10.1016/j.lungcan.2010.06.002

[9] ANEJA R, GHALEB AM, ZHOU J, YANG VW, JOSHI HC p53 and p21 determine the sensitivity of noscapine-induced apoptosis in colon cancer cells. Cancer Res 2007; 67: 3862 3870. http://dx.doi.org/10.1158/0008-5472.CAN-06-4282 
[10] MADAN J, GUNDALA SR, KASETTI Y, BHARATAM PV, ANEJA R et al. Enhanced noscapine delivery using estrogen-receptor-targeted nanoparticles for breast cancer therapy. Anticancer Drugs 2014; 25: 704-716. http://dx.doi. org/10.1097/cad.0000000000000098

[11] QI Q, HE K, YOO MH, CHAN CB, LIU X et al. Acridine yellow $\mathrm{G}$ blocks glioblastoma growth via dual inhibition of epidermal growth factor receptor and protein kinase C kinases. J Biol Chem 2012; 287: 6113-6127. http://dx.doi. org/10.1074/jbc.M111.293605

[12] ANEJA R, DHIMAN N, IDNANI J, AWASTHI A, ARORA SK et al. Preclinical pharmacokinetics and bioavailability of noscapine, a tubulin-binding anticancer agent. Cancer Chemother Pharmacol 2007; 60: 831-839. http://dx.doi. org/10.1007/s00280-007-0430-y

[13] JACKSON T, CHOUGULE MB, ICHITE N, PATLOLLA RR, SINGH M Antitumor activity of noscapine in human non-small cell lung cancer xenograft model. Chemother Pharmacol 2008; 63: 117-126. http://dx.doi.org/10.1007/ $\underline{\mathrm{s} 00280-008-0720-\mathrm{Z}}$

[14] SARKISSIAN T, TIMMONS A, ARYA R, ABDELWAHID E, WHITE K. Detecting apoptosis in Drosophila tissues and cells. Methods 2014; 68: 89-96. http://dx.doi.org/10.1016/j. ymeth.2014.02.033

[15] MELliER G, LiU D, BELlOT G, HOLME AL, PERVAIZ Small molecule sensitization to TRAIL is mediated via nuclear localization, phosphorylation and inhibition of chaperone activity of Hsp27. Cell Death Dis 2013; 4: e890. http://dx.doi. org/10.1038/cddis.2013.413

[16] GU H, YOU Q, LIU W, YANG Y, ZHAO L et al. Gambogic acid induced tumor cell apoptosis by $\mathrm{T}$ lymphocyte activation in H22 transplanted mic. Int Immunopharmacol 2008; 8: 1493-1502. http://dx.doi.org/10.1016/j.intimp.2008.05.013

[17] LI C, QI Q, LU N, DAI Q, LI F et al. Gambogic acid promotes apoptosis and resistance to metastatic potential in MDA-MB231 human breast carcinoma cells. Biochem Cell Biol 2012; 90: 718-730. http://dx.doi.org/10.1139/o2012-030

[18] LOZANO R, NAGHAVI M, FOREMAN K, LIM S, SHIBUYA Ket al. Global and regional mortality from 235 causes of death for 20 age groups in 1990 and 2010: a systematic analysis for the Global Burden of Disease Study 2010. Lancet2012; 380: 20952128. http://dx.doi.org/10.1016/S0140-6736(12)61728-0

[19] MARIN JJ, ROMERO MR, BRIZ O Molecular bases of liver cancer refractoriness to pharmacological treatment. Curr Med Chem 2010; 17: 709-740. http://dx.doi. org/10.2174/092986710790514462

[20] LANDEN JW, LANG R, MCMAHON SJ, RUSAN NM, YVON AM et al. Noscapine alters microtubule dynamics in living cells and inhibits the progression of melanoma. Cancer Res 2002; 62: 4109-4114.

[21] MADAN J, PANDEY RS, JAIN UK, KATARE OP, ANEJA $\mathrm{R}$ et al. Sterically stabilized gelatin microassemblies of noscapine enhance cytotoxicity, apoptosis and drug delivery in lung cancer cells. Colloids Surf B Biointerfaces 2013; 107: 235-244. http://dx.doi.org/10.1016/j. colsurfb.2013.02.010

[22] NEWCOMB EW, LUKYANOV Y, SMIRNOVA I, SCHNEE T, ZAGZAG D. Noscapine induces apoptosis in human glioma cells by an apoptosis-inducing factor-dependent pathway. Anticancer Drugs 2008; 19: 553-563. http://dx.doi.org/10.1097/ CAD.0b013e3282ffd68d

[23] MADAN J, BARUAH B, NAGARAJU M, ABDALLA MO, YATES $C$ et al. Molecular cycloencapsulation augments solubility and improves therapeutic index of brominated noscapine in prostate cancer cells. Mol Pharm 2012; 9: 1470-1480. http://dx.doi.org/10.1021/mp300063v

[24] LIU M, LUO XJ, LIAO F, LEI XF, DONG WG Noscapine induces mitochondria-mediated apoptosis in gastric cancer cells in vitro and in vivo. Cancer Chemother Pharmacol 2011; 67: 605-612. http://dx.doi.org/10.1007/s00280-010$\underline{1356-3}$

[25] YE K, KE Y, KESHAVA N, SHANKS J, KAPP JA et al. Opium alkaloid noscapine is an antitumor agent that arrests metaphase and induces apoptosis in dividing cells. Proc Natl Acad Sci U S A 1998; 95: 1601-1606. http://dx.doi.org/10.1073/ pnas.95.4.1601

[26] RAISOVA M, HOSSINI AM, EBERLE J, RIEBELING C, WIEDER $\mathrm{T}$ et al. The Bax/Bcl-2 ratio determines the susceptibility of human melanoma cells to CD95/Fas-mediated apoptosis. J Invest Dermatol 2001; 117: 333-340. http://dx.doi. org/10.1046/j.0022-202x.2001.01409.x

[27] PERLMAN H, ZHANG X, CHEN MW, WALSH K, BUTTYAN R An elevated bax/bcl-2 ratio corresponds with the onset of prostate epithelial cell apoptosis. Cell Death Differ 1999; 6: 48-54. http://dx.doi.org/10.1038/sj.cdd.4400453

[28] ZHU L, HAN MB, GAO Y, WANG H, DAI L et al. Curcumin triggers apoptosis via upregulation of $\mathrm{Bax} / \mathrm{Bcl}-2$ ratio and caspase activation in SW872 human adipocytes. Mol Med Rep 2015; 12: 1151-1156. http://dx.doi.org/10.3892/ $\underline{\mathrm{mmr} .2015 .3450}$

[29] CHUEH WH, LIN JY. Berberine, an isoquinoline alkaloid, inhibits streptozotocin-induced apoptosis in mouse pancreatic islets through down-regulating $\mathrm{Bax} / \mathrm{Bcl}-2$ gene expression ratio. Food Chem 2012; 132: 252-260. http:// dx.doi.org/10.1016/j.foodchem.2011.10.065

[30] Li B, DOU QP Bax degradation by the ubiquitin/proteasomedependent pathway: involvement in tumor survival and progression. Proc Natl Acad Sci U S A 2000; 97: 3850-3855. http://dx.doi.org/10.1073/pnas.070047997

[31] Ho YS, Lee HM, ChANG CR, LIN JK Induction of Bax protein and degradation of lamin A during p53-dependent apoptosis induced by chemotherapeutic agents in human cancer cell lines. Biochem Pharmacol 1999; 57: 143-154. http://dx.doi. org/10.1016/S0006-2952(98)00272-X 


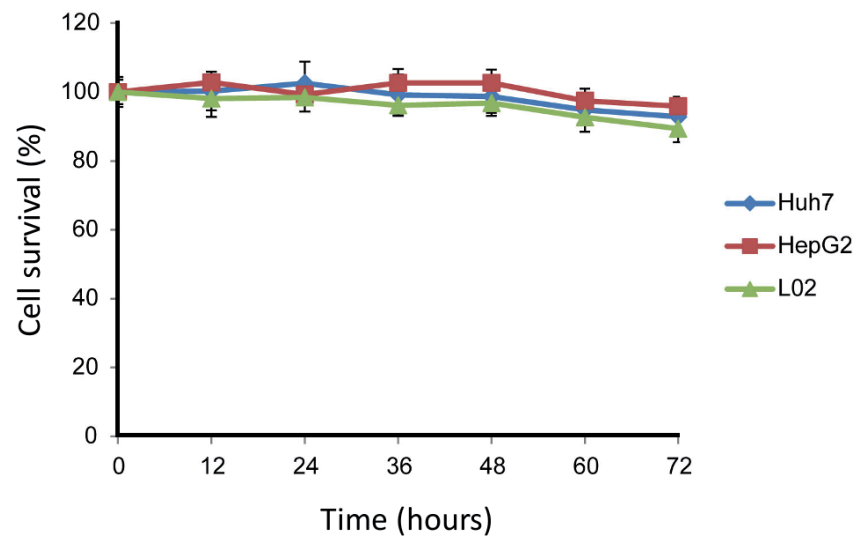

Supplemental figure 1. Effect of vehicle (DMSO) at the concentrations corresponding IC50 values on proliferation of HepG2, Huh7, and L02 cells, respectively. HepG2, Huh7, and L02 cells were treated with DMSO at the concentrations corresponding IC50 values followed by MTT assay examining cell proliferation. No notable difference was examined during the treatment period. 